\title{
Judicial Control and the Recovery Phase
}

State aid control has traditionally been described as a 'bilateral' procedure between the Commission and the Member States. The latter in particular are jealously attached to this allegedly exclusive partnership and rarely miss an opportunity of heralding it urbi et orbe. The Commission is normally more discreet about it, perhaps realising that a purely bilateral relationship with the Member States might not be the best option for an efficient State aid control. Perhaps for the same reason the Member States have always rejected the (modest) proposals by the Commission to expand the rights of third parties in the procedural regulation. At the end of the day, the Member States prefer to deal bilaterally with the Commission without the uncomfortable presence of third parties.

However, this 'bilateral' character may be true, but it is not the whole truth. The role of third parties, like beneficiaries or complainants, has always existed. The text of Article 108.3 TFEU is clear enough by referring explicitly to the obligation for the Commission to request the views of 'the parties concerned' within the formal administrative procedure. By the way, the same Treaty does not refer at all to 'recovery' and this has never been perceived as an obstacle for considering it a central notion to State aid control.

It is true that the precise scope of the participation by third parties had to be defined by secondary legislation, by the case law and/or by the Commission's practice. In actual terms, it is mainly due to the case law that this role of third parties has become quite significant today, at least in certain phases of the procedure. Secondary legislation has only codified the previous case law and has never taken any further steps.

As of today, third parties are no longer mere 'sources of information' for the Commission but also have certain minimal rights during the formal procedure and also, indirectly, in the preliminary procedure. They can at least challenge decisions adopted at the end of the preliminary phase and, if they fulfil the high locus standi requirement, also final decisions. We can therefore find many examples of positive decisions quashed following annulment actions by complainants and also many examples of negative decisions quashed by actions brought by the beneficiaries (often without the intervention of the Member State). It is obvious that, without such actions by beneficiaries and complainants, State aid law would be in a very different place today.

Judicial review of formal State aid decisions seems therefore reasonably established nowadays. However, are formal Commission decisions always the place where State aid control is actually happening? Or is the actual control done elsewhere in some cases?

We are indeed seeing more and more negative decisions ordering recovery in principle but at the same time leaving open issues like the identity of the beneficiaries, the precise amount of aid to be recovered or even the possible compatibility of individual aids within a scheme. According to the case law it is enough that decisions contain the main parameters for subsequent identification and calculation of the aid. Those 'open negative decisions' often refer to schemes but sometimes also to individual aid. The 'small details' left behind are not really decided in the decision (the one subject to judicial review) but later on in the so called 'recovery phase'.

It therefore becomes essential to understand what this 'recovery phase' means, both legally and factually. 
Legally speaking, the Member State to which a decision is addressed has sole competence to implement it according to its internal procedures. In the case of open negative decisions, this means that the Member State would be - in theory - the one determining 'small issues' like the identity of the beneficiaries or the amounts to be recovered. It is only if and when the Member State faces doubts or difficulties that it can ask for the assistance of the Commission. After all, both sides are supposed to cooperate in good faith. In theory the Commission can only give its advice; it cannot oblige the Member State to act in a certain way. However, if the Commission considers that the Member State has not properly executed its decision (ie if it has not followed its advice), it can bring an infringement procedure against it before the Court of Justice. This usually gives the Member State a strong incentive to follow the Commission's 'advice'.

One serious problem with this 'recovery' procedure is that it entirely lacks transparency towards third parties. In principle, neither beneficiaries nor competitors have any formal role to play here. They are left into the total darkness of a purely bilateral dialogue between the Commission and the Member State.

One could try to delude oneself by relying on the myth that the Member State and the beneficiary share the same interest. This is however just a myth that often does not correspond with reality. Indeed, in the recovery phase in particular, the interest of the beneficiary and of the Member State could not be more opposed. While the beneficiary must pay back the aid received, the Member State only faces the perspective of getting its money back with interest. It is simply absurd to assume that the beneficiary's interest in the recovery phase would necessarily be protected by the Member State.

There may be certain cases in which the Member State actually gives some information to the beneficiary in an informal way. One also has the impression that sometimes the Commission keeps the complainant informed to a certain degree. Both situations are however informal arrangements decided by the main parties on a random basis, not a transparent exercise of clearly defined rights. Even more worryingly, this modus operandi might actually lead to the impossibility of judicial review concerning the recovery phase.

Indeed, it is not simply that third parties do not have any right to influence and to be informed about the decisions taken in the recovery phase as third party. They may even face in certain cases a raw denial of the existence of any decision, either by the Commission or by the Member State. In other words, you may find yourself as beneficiary in the surrealistic scenario of having to pay back the aid without knowing who exactly asks you to do so. As a consequence, you may not even have any way of opposing the (non-)decision taken (or not) in the recovery phase.

This may sound exaggerated to anyone not having had to deal with a 'recovery procedure'. Unfortunately, they may become quite real. The recent Order T-170/16 Guardian Glass ${ }^{1}$ offers an interesting and perhaps extreme example. In this case the General Court held that the Commission's view on compatibility (an area within its exclusive competence) cannot be subject to judicial review when expressed in the recovery phase.

At some point, all the bilateral dialogue between the Commission and the Member State on the execution of a recovery decision is followed by an act by the national authority asking the alleged beneficiary for a certain amount to be paid back. The reasoning of such an act refers to the obligation to implement the previous Commission decision. However, if the decision 
was an open negative one (without specifying the identity of the beneficiary, the amount to be recovered or even the possible compatibility of the aid) that reference will not be enough. The Member State is likely to refer then to certain mysterious 'indications' by the Commission allegedly granted at bilateral meetings. Those are often just oral statements or, at most, adopt the form of a non-paper which is not dated or signed by anyone and whose origin at the Commission is a pure matter of faith. The Member State makes clear however that it considers the said indications to be rather a mandate, since otherwise it could face an infringement action in front of the Court of Justice.

If the beneficiary then asks the Commission to confirm or deny the paternity of such paper, it is likely to receive a non sequitur as an answer: after all, the recovery phase is a purely bilateral process between the Commission and the Member State, covered by a veil much like the 'confession secrecy' of the Catholic Church. It goes without saying that this convenient silence by the Commission makes it extremely difficult to identify any Commission act that could be subject to judicial review by the EU Courts.

Legally speaking, the situation should be clear. The recovery act has been adopted by the Member State and - failing a compulsory Commission decision - must be attributed only to it. Since the said compulsory decision will never appear, national judges will be entirely free to decide on the merits of the national recovery act. They will be entirely free to disagree with the informal indications coming (perhaps) from the Commission. If the Commission does not take responsibility, it cannot impose its view either, at least from a legal point of view. This is what the case law tells us in cases like Mediaset $^{2}$ and in the more recent Guardian Glass. ${ }^{3}$

The Commission is of course aware of this reality, but it also hopes that, in the majority of cases, its point of view will actually prevail, not based on any legal effects but on its auctoritas over the Member State. In other words, the Commission might be able to produce actual effects in the recovery phase without assuming any legal responsibility or being subject to judicial review. What would seem a dream for any institution in any other legal area becomes a reality in the recovery phase!

The problem arises when we are speaking not of minor technical details, but of elements as central as the identity of the beneficiaries, the determination of the amount of aid (after the Mediaset case, we know that it can be zero) or even the compatibility (on which the Commission has exclusive competence). It seems quite obvious that the Commission cannot leave the determination of such essential elements to any other entity and, in particular, to the Member State which granted the illegal aid. This would breach not only the Meroni case law ${ }^{4}$ but also common sense.

That is why, in practice, the Commission does not actually do that. On the contrary, it normally keeps a rather strict control over the steps taken by the Member State during the recovery phase. This is in particular the case with open negative decisions. This makes sense and speaks favourably of the professionalism of the services in charge of recovery. The problem lies not in the Commission's practical attitude on recovery but on the fact that some decisions either should not belong to the recovery phase or should in any event be challengeable before the EU Courts.

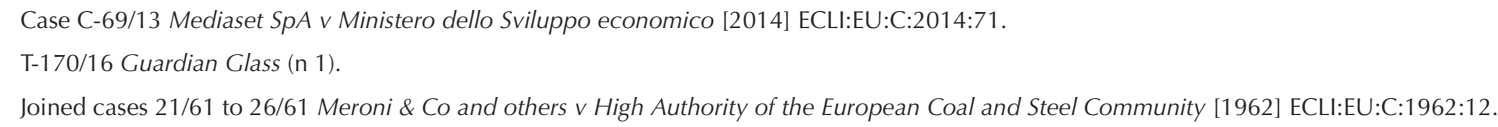


The resulting situation may be more than paradoxical. We may indeed have years of sophisticated legal disputes on the State aid character of a measure, its compatibility or the existence of legitimate expectations, with opening and final Commission decisions, actions in front of the General Court and appeals before the Court of Justice. The final (final?) outcome of all this may well be that the negative decision is confirmed. And then, during the 'recovery phase' someone decides that the amount to be recovered is zero after all! Or the opposite, that the amount to be recovered is more than the advantage received! It seems quite obvious that such recovery decisions are at least as important - if not more so - than the formal decisions that were supposed to be 'final'. It does not make any sense to have legal review of the latter and not of the former.

In our opinion, in the $21^{\text {st }}$ century the recovery phase can no longer be left in the shadows of purely bilateral arrangements between the Commission and the Member State, in particular when the formal decision has not decided on essential issues. Recovery decisions have to be formal decisions that must be compulsory for the Member States but also subject to similar guarantees for all the parties, including beneficiaries and complainants, and subject to control by EU Courts.

This would not require any change in the procedural regulation and, therefore, would not require the (unlikely) approval by the Member States at the Council. It would just require that the Commission finally recognizes its paternity of its recovery decisions and applies to them the rules applicable to all its other decisions.

In our opinion, this is not just a legal requirement but would also be in the long term EU interest: making State aid control more a legal and economic matter, less exposed to the risks of political pressures by some Member States.

José Luis Buendía Sierra Managing Editor 